\title{
PERBEDAAN STATUS GIZI ANTARA BAYI USIA 0-6 BULAN DENGAN PEMBERIAN ASI SECARA EKSKLUSIF DAN TIDAK SECARA EKSKLUSIF DI PUSKESMAS KAMPUNG DALAM TAHUN 2018
}

\author{
Yuliana $^{1}$, Melyani $^{2}$
}

Akademi Kebidanan Panca Bhakti Pontianak

Email korespondensi: akbidpbpontianak@gmail.com

\begin{abstract}
Abstrak
Data Kemenkes RI (2017), memperlihatkan bahwa terdapat 4.770.444 jumlah bayi yang ada di Indonesia. Diantara keseluruhan bayi di Indonesia hanya terdapat 29,5\% bayi yang mendapat ASI Eksklusif usia 6 bulan Menurut hasil Riskesdas didalam Data Kemenkes RI (2017), bahwa terdapat jumlah balita gizi buruk dan kurang masih sebesar $19,6 \%$. Indonesia masih menjadi negara dengan anak berstatus gizi buruk. Sebab, saat ini gizi balita di Indonesia berada di bawah standar yang di tetapkan WHO yakni dibawah $10 \%$. Tujuan penelitian ini adalah untuk mengetahui Perbedaan Status Gizi antara Bayi Usia 6 Bulan yang Diberi ASI Eksklusif dan Tidak Eksklusif di Puskesmas Kampung Dalam Kecamatan Pontianak Timur Tahun 2018. Metode penelitian ini menggunakan desain penelitian analitik komparatif dengan pendekatan cross sectional, total populasi pada penelitian ini sebanyak 148 orang sedangkan sampel yaitu 60 orang. Hasil penelitian yang telah dilakukan didapatkan sebagian besar responden mempunyai bayi yang diberi ASI Eksklusif dengan status gizi normal yaitu 26 orang (86,7\%) dan bayi yang diberi ASI Eksklusif dengan status gizi abnormal yaitu 4 orang $(13,3 \%)$. Sedangkan bayi yang tidak diberi ASI Eksklusif dengan status gizi normal yaitu 16 orang $(53,3 \%)$ dan 14 orang $(46,7 \%)$ bayi yang tidak diberi ASI Eksklusif dengan status gizi abnormal. Hasil uji statistik Mann Whitney $U$ didapatkan nilai $Z$ sebesar -3.894 dengan taraf signifikansi (p) 0,000 atau probabilitas dibawah $0,05(0,000<0,05)$ yang artinya $\mathrm{H}_{\mathrm{o}}$ ditolak. Kesimpulan pada penelitian ini yaitu ada perbedaan status gizi antara bayi usia 6 bulan yang diberi ASI Eksklusif dan tidak diberikan ASI Eksklusif di Puskesmas Kampung Dalam Tahun 2018.Saran untuk Puskesmas Kampung Dalam agar dapat lebih mengoptimalkan pemberian konseling, penyuluhan dan pendidikan kesehatan kepada ibu yang memiliki bayi usia 0-6 bulan untuk memberikan ASI secara Eksklusif yang bertujuan untuk perbaikan status gizi bayi usia 0-6 bulan.
\end{abstract}

Kata Kunci $\quad$ : ASI Eksklusif, Tidak ASI Eksklusif, Status Gizi, Bayi usia 6 bulan

\section{Pendahuluan}

Berdasarkan pengukuran antropometri, anak yang sehat akan bertambah umur, bertambah berat badan dan tinggi badan dikaitkan dengan kecukupan asupan makronutrien, kalsium, magnesium, fosfor, vitamin $\mathrm{D}$, yodium dan zinc. Parameter antropometri merupakan dasar dari penilaian status gizi. Kombinasi antara beberapa parameter di sebut indeks antropometri. Faktor umur sangat penting dalam menentukan status gizi. Hasil pengukuran tinggi badan dan berat badan yang akurat menjadi tidak berarti bila

\footnotetext{
${ }^{1}$ Dosen Akademi Kebidanan Panca Bhakti Pontianak

${ }^{2}$ Dosen Akademi Kebidanan Panca Bhakti Pontianak
}

tidak disertai dengan penentuan umur yang tepat (Susilowati, 2016).

Standar acuan status gizi di Indonesia masih dinilai dengan cara pengukuran Berat Badan menurut umur $(\mathrm{BB} / \mathrm{U})$, Berat Badan menurut Tinggi Badan (BB/TB) dan Tinggi Badan menurut umur (TB/U). Sementara klasifikasinya adalah normal, underweight (kurus) dan gemuk. Standar pedoman yang digunakan adalah standar berdasarkan tabel World Health Organization (WHO) - National Center For Health Statistics (NCHS). Status gizi bayi dan balita dapat diketahui dengan 
mencocokan umur (dalam bulan) dengan berat badan standar tabel WHO-NCHS, bila berat badannya kurang, maka status gizinya kurang (Marimbi, 2010).

$$
\text { Data Kemenkes RI (2017), }
$$
memperlihatkan bahwa terdapat 4.770 .444 jumlah bayi yang ada di Indonesia. Diantara keseluruhan bayi di Indonesia hanya terdapat $29,5 \%$ bayi yang mendapat ASI Eksklusif usia 6 bulan. Menurut hasil Riskesdas didalam Data Kemenkes RI (2017), bahwa terdapat jumlah balita gizi buruk dan kurang masih sebesar $19,6 \%$. Indonesia masih menjadi negara dengan anak berstatus gizi buruk. Sebab, saat ini gizi balita di Indonesia berada di bawah standar yang di tetapkan WHO yakni dibawah $10 \%$. Indonesia menduduki peringkat ke 3 , dimana peringkat pertama dan kedua diduduki oleh Negara Timor Leste dan Laos.

Berdasarkan hasil laporan program gizi Dinas Kesehatan Provinsi Kalimantan Barat Tahun 2017, dari seluruh Kabupaten/Kota yang ada terdapat 6,6\% kasus gizi buruk dan 17,9\% kasus gizi kurang berdasarkan berat badan per umur (BB/U). Jika dibandingkan dengan angka prevalensi tahun 2016 (5,5\%) dan tahun 2017 $(6,6 \%)$ terlihat meningkat. Angka tersebut didapatkan dari laporan kasus dilihat berdasarkan tanda-tanda klinis kasus gizi buruk. Provinsi Kalimantan Barat termasuk persentase gizi buruk tertinggi di Indonesia. Hasil pemantauan status gizi yang dilakukan Kementerian Kesehatan pada tahun 2017 menunjukkan bahwa $24,5 \%$ bayi di Provinsi dengan ibukota Pontianak tersebut mengalami kekurangan gizi. Dinas Kesehatan Kota
Pontianak, Provinsi Kalimantan Barat, mencatat dalam dua tahun terakhir yakni tahun 2016 hingga 2017 tercatat sebanyak 3 orang bayi dan 4 orang balita yang meninggal diakibatkan karena kasus gizi buruk.

Berdasarkan penelitian yang dilakukan Susilowati, Kusharisupeni, Sandra Fikawati dan Kusdinar Achmad (2010), bahwa salah satu penyebab kurus, pendek, dan gemuk pada anak umur 12-24 bulan adalah durasi pemberian ASI yang tidak optimal. Korelasi tertinggi terjadi pada durasi pemberian ASI dengan kejadian pendek pada anak $(\mathrm{r}=0,004)$ hasil analisis rekresi linear ganda menunjukkan bahwa durasi pemberian ASI mempengaruhi tinggi badan anak sebesar 0,790. Angka ini lebih tinggi dibandingkan variabel lain: ASI Eksklusif $(0,685)$, diare $(0,086)$, status ibu bekerja $(0,209)$, pengetahuan ibu $(0,186)$, asupan energi $(0,260)$ dan asupan protein $(0,083)$ (Susilowati, 2016).

WHO menyampaikan rekomendasi pemberian ASI Eksklusif 6 bulan dan Makanan Pendamping-ASI setelahnya dengan tetap memberikan ASI hingga 2 tahun. Pertumbuhan bayi adalah indikator proksi dari produksi ASI dan kecukupan pemberian ASI. Maka pemantauan status gizi bayi penting dilakukan untuk mengetahui cukup atau tidaknya ASI yang diberikan (Ahmad, 2015 dalam Fikawati, 2015).

Bayi yang diberi ASI Eksklusif akan terpenuhi kebutuhan gizinya secara maksimal sehingga dia akan lebih sehat, lebih tahan terhadap infeksi, tidak mudah terkena alergi, dan lebih jarang sakit. Sebagai hasilnya, bayi 
yang mendapatkan ASI Eksklusif akan mengalami pertumbuhan dan perkembangan yang optimal. Pertumbuhan dapat dilihat dari penambahan berat badan, tinggi badan, ataupun lingkar kepala sedangkan perkembangan yang optimal dapat dilihat dari adanya peningkatan kemampuan motorik, psikomotorik dan bahasa (Sulistyoningsih, 2011).

Adapun jumlah bayi yang diberi ASI secara Eksklusif dan tidak secara Eksklusif di bulan Januari dan Februari tahun 2018 yakni sebanyak 326 bayi dan hanya 148 bayi yang berusia 6 bulan dan datang berkunjung ke puskesmas. Dari jumlah bayi yang datang berkunjung ke puskesmas tersebut, terdapat 2 bayi yang mengalami gizi kurang dalam penanganan dari pihak puskesmas.

Berdasarkan data dan studi pendahuluan yang dilakukan diketahui bahwa terdapat perbedaan status gizi bayi yang di beri ASI Eksklusif dan tidak diberi ASI Eksklusif di Puskesmas Kampung Dalam Tahun 2018. Oleh karena itu, peneliti tertarik melakukan penelitian mengenai "Perbedaan Status Gizi Antara Bayi usia 0-6 bulan dengan Pemberian ASI secara Eksklusif dan Tidak secara Eksklusif di Puskesmas Kampung Dalam Tahun 2018".

\section{Metode}

Penelitian ini merupakan penelitian analitik komparatif dengan pendekatan cross sectional. Penelitian ini dilakukan pada bulan Februari hingga Mei tahun 2018 di Wilayah Kerja Puskesmas Kampung Dalam Kecamatan Pontianak Timur. Dalam penelitian ini, populasi yang digunakan adalah jumlah bayi usia 6 bulan periode bulan Januari dan Februari tahun 2018 di Wilayah Kerja Puskesmas Kampung Dalam sebanyak 148 orang. Total sampel dalam penelitian ini adalah sebanyak 60 orang bayi usia 6 bulan yang dibagi menjadi 2 kelompok diantaranya 30 orang yang diberi ASI secara Eksklusif dan 30 orang yang diberi ASI tidak secara Eksklusif.

\section{Hasil dan Pembahasan}

Tabel 1. Status Gizi Bayi Usia 6 Bulan yang diberi ASI secara Eksklusif

\begin{tabular}{ccc}
\hline Status Gizi & \multicolumn{2}{c}{ ASI Eksklusif } \\
\cline { 2 - 3 } & $\mathrm{F}$ & $\%$ \\
\hline Gizi Buruk & 2 & 6,7 \\
Gizi Kurang & 8 & 2,6 \\
Gizi Baik & 20 & 66,7 \\
\hline
\end{tabular}

Tabel diatas memperlihatkan bahwa sebagian besar dari responden mempunyai bayi yang diberi ASI secara Eksklusif dengan status gizi baik yaitu sebanyak 20 orang $(66,7 \%)$, sangat sedikit dari responden dengan status gizi buruk sebanyak 1 orang $(3,3 \%)$ dan tidak ada sedikitpun responden yang memiliki status gizi lebih. 
Tabel 2. Status Gizi Bayi Usia 6 Bulan yang tidak diberi ASI secara Eksklusif

\begin{tabular}{ccc}
\hline \multirow{2}{*}{ Status Gizi } & \multicolumn{2}{c}{ Tidak ASI Eksklusif } \\
\cline { 2 - 3 } & $\mathrm{F}$ & $\%$ \\
\hline Gizi Buruk & 7 & 23,3 \\
Gizi Kurang & 12 & 40 \\
Gizi Baik & 11 & 36,7 \\
\hline
\end{tabular}

Berdasarkan tabel 2 diatas, dapat diketahui bahwa sebagian dari responden mempunyai bayi yang tidak diberi ASI secara Eksklusif dengan status gizi kurang yaitu 12 orang (40\%), sebagian kecil dari responden yang memiliki status gizi buruk sebanyak 7 orang $(23,3 \%)$ dan tidak ada sedikitpun dari responden yang memiliki status gizi lebih.

Simarmata (2009) mengatakan status gizi merupakan keadaan tubuh sebagai akibat konsumsi makanan dan penggunaan zat gizi. Dibedakan atas status gizi buruk, gizi kurang, gizi baik, dan gizi lebih. Status gizi sangat dipengaruhi oleh asupan gizi. Status gizi diartikan sebagai status kesehatan yang dihasilkan oleh keseimbangan antara kebutuhan dan masukan zat gizi. Status gizi sangat ditentukan oleh ketersediaan zat gizi dalam jumlah cukup dan dalam kombinasi waktu yang tepat di tingkat sel tubuh agar berkembang dan berfungsi secara normal.

Fikawati (2015) mengatakan ASI Eksklusif adalah pemberian ASI saja tanpa makanan dan minuman tambahan lain pada bayi berusia 0-6 bulan. Bahkan air putih tidak diberikan dalam tahap ASI Eksklusif ini. Bayi yang diberi ASI secara Eksklusif relatif memiliki status gizi serta pertumbuhan yang normal dikarenakan terdapat banyak manfaat dari kandungan ASI tersebut yakni sumber gizi yang sangat ideal, komposisi ASI sangat tepat bagi kebutuhan tumbuh kembang bayi berdasarkan usianya, tidak memberatkan fungsi saluran pencernaan dan ginjal, mengandung berbagai zat antibodi sehingga mencegah terjadinya infeksi yakni menjaga daya tahan tubuh bayi terhadap infeksi serta jumlah dan proporsi zat gizi yang terkandung pada ASI sudah tepat dan ideal untuk kebutuhan bayi.

Khazanah (2011) mengatakan bahwa pemberian Non ASI Eksklusif atau susu formula pada bayi merupakan salah satu solusi selain pemberian ASI. Namun kandungan susu formula yang beragam dapat mengakibatkan bayi mengalami gizi kurang ataupun gizi lebih (kegemukan). Susu formula mempunyai banyak kelemahannya karena terbuat dari susu sapi, antara lain; kurang praktis karena harus dipersiapkan terlebih dahulu, tidak dapat bertahan lama, mahal dan tidak selalu tersedia, cara penyajian harus tepat jika tidak akan dapat menyebabkan alergi atau gangguan pencernaan, kandungan susu formula tidak selengkap ASI, pengenceran yang salah, kontaminasi mikroorganisme, bayi bisa diare dan sering muntah, menyebabkan bayi terkena infeksi, obesitas atau kegemukan. Sehingga memungkinkan cukup besar bayi yang mengkonsumsi susu formula akan mengalami gizi kurang ataupun gizi lebih.

Bayi yang diberi ASI Eksklusif secara keseluruhan memiliki berat badan normal dan 
tidak ada yang mengalami kegemukan (obesitas) bahkan kurang gizi. Sehingga ASI merupakan makanan utama, terbaik dan alami pertama untuk bayi yang diberikan tanpa makanan tambahan sekurang-kurangnya sampai usia 6 bulan. Karena didalam ASI terkandung zat-zat kekebalan, anti infeksi dan nutrisi yang dibutuhkan bayi untuk tumbuh kembang secara optimal (normal) serta mengontrol terjadinya kelebihan berat badan atau obesitas.

Hasil penelitian ini didukung dengan hasil penelitian yang dilakukan oleh Kurnia (2013), tentang hubungan pemberian ASI Eksklusif dengan status gizi bayi usia 6 bulan di Kampung Kajanan, Buleleng menunjukkan hasil uji korelasi $\mathrm{p}=0,000(\mathrm{p}<0,05)$ sehingga dapat disimpulkan adanya kecenderungan bahwa ibu yang memberikan ASI Eksklusif memiliki bayi dengan status gizi lebih baik dari pada ibu yang tidak memberikan ASI Eksklusif.

Sependapat dengan penelitian yang dilakukan oleh Sularno (2012) dengan judul penelitian hubungan pemberian ASI Eksklusif dan status gizi bayi dengan frekuensi diare pada bayi usia 0-4 bulan di Puskesmas Warungasem Kabupaten Batang Tahun 2012 didapatkan hasil bahwa sebagian besar bayi yang tidak diberi ASI Eksklusif memiliki gizi kurang sdeangkan bayi yang diberi ASI Eksklusif memiliki gizi baik.

Menurut peneliti, faktor yang mempengaruhi rendahnya pemberian ASI Eksklusif karena kurangnya pengetahuan dan kesadaran ibu akan pentingnya pemberian ASI dan manfaat ASI bagi ibu dan bayi, petugas dan pelayanan kesehatan yang kurang mendukung program peningkatan pemberian ASI. Adapun faktor yang menyebabkan status gizi bayi kurang dikarenakan tidak mengkonsumsi ASI secara Eksklusif yakni pemberian air putih yang hanya mengandung mineral, pemberian susu formula yang hanya diberi pada saat bayi menangis saja yang seharusnya pemberian susu formula diberikan minimal 2 jam sekali hingga 3 jam sekali, dan penyajian susu formula yang tidak praktis dibandingkan pemberian ASI yakni botol susu yang harus higienis, penyajiannya harus diseduh dengan air hangat terlebih dahulu, jika penyajiannya tidak seperti demikian akan menyebabkan gangguan saluran pencernaan (diare) pada bayi.

Penilaian status gizi anak sangatlah penting dilakukan untuk mendeteksi dini malnutrisi pada anak, baik itu kelebihan ataupun kekurangan gizi. Oleh sebab itu, penting sekali orang tua memantau pertumbuhan anak dengan rutin mengecek ke posyandu atau pelayanan kesehatan terdekat. Pada petugas kesehatan dapat melakukan konseling atau pendidikan kesehatan yang berkaitan dengan pemenuhan nutrisi pada bayi usia 6 bulan.

Pemberian Non ASI Eksklusif atau susu formula pada bayi merupakan salah satu solusi selain pemberian ASI. Namun ibu harus memberikan susu formula pada bayi secara tepat yang meliputi waktu pemberiannya dan cara penyajiannya agar bayi mendapatkan nutrisi yang cukup untuk pertumbuhannya serta tidak mengalami gangguan komplikasi dikarenakan penyajiannya yang tidak higienis. 
Tabel 3. Analisa Perbedaan Status Gizi

\begin{tabular}{|c|c|c|c|c|c|c|}
\hline \multirow{3}{*}{ Status Gizi } & \multicolumn{4}{|c|}{ Pemberian ASI } & \multirow{3}{*}{ Z } & \multirow{3}{*}{$P$-Value } \\
\hline & \multicolumn{2}{|c|}{ ASI Eksklusif } & \multicolumn{2}{|c|}{ Tidak ASI Eksklusif } & & \\
\hline & $\mathrm{F}$ & $\%$ & $\mathrm{~F}$ & $\%$ & & \\
\hline Gizi Buruk & 2 & 6,7 & 7 & 23,3 & & \\
\hline Gizi Kurang & 8 & 2,6 & 12 & 40 & -2.462 & 0,014 \\
\hline Gizi Baik & 20 & 66,7 & 11 & 36,7 & & \\
\hline
\end{tabular}

Hasil uji statistik Mann Whitney $U$ didapatkan nilai $\mathrm{Z}$ sebesar -2.462 dengan taraf signifikansi (p) 0,014 atau probabilitas dibawah $0,05(0,014<0,05)$. Sehingga memberikan kesimpulan $\mathrm{H}_{\mathrm{o}}$ ditolak atau ada perbedaan status gizi antara bayi usia 6 bulan dengan pemberian ASI secara Eksklusif dan tidak secara Eksklusif di Puskesmas Kampung Dalam Tahun 2018.

Fikawati (2015) mengatakan bahwa bayi yang tidak mendapatkan ASI Eksklusif akan mengalami gangguan pertumbuhan dan perkembangan disamping mengalami gizi buruk. Bayi yang mendapat ASI umumnya tumbuh dengan cepat pada 2 sampai 3 bulan pertama kehidupannya, tetapi lebih lambat dibanding bayi yang tidak mendapat ASI Eksklusif. Bayi yang mendapat ASI Eksklusif lebih baik pertumbuhannya, memiliki kecerdasan yang tinggi dan daya tahan tubuh yang lebih baik.

Pertumbuhan diukur berdasarkan perubahan indeks masa tubuh yang meliputi berat badan, tinggi badan, lingkar lengan, lingkar kepala. Dari hasil penelitian ini, tampak jelas adanya perbedaan bahwa status gizi bayi yang diberi ASI Eksklusif lebih baik dibandingkan dengan tidak Eksklusif, namun tidak ditemukan status gizi lebih (obesitas).
Yang ditemukan pada penelitian ini adalah pemberian susu formula pada bayi yang cenderung mengakibatkan status gizi kurang bahkan status gizi buruk.

Penelitian ini didukung dengan hasil penelitian yang dilakukan oleh Hapsari (2012) dengan judul penelitian perbedaan status gizi bayi usia 0-6 bulan yang diberi ASI Eksklusif dan tidak Eksklusif di BPS Suratni Bantul Yogyakarta didapatkan hasil bahwa status gizi bayi usia 0-6 bulan yang diberi ASI Eksklusif di BPS Suratni Bantul Yogyakarta sebagian besar adalah gizi baik yaitu 12 orang (80\%) sedangkan bayi yang tidak diberi ASI Eksklusif sebagian besar dengan status gizi kurang yaitu 11 orang (73,3\%). Hasil uji Mann Whitney didapatkan nilai $Z$ sebesar -3.290 dengan signifikansi (p) 0,001 sehingga memberikan kesimpulan bahwa terdapat perbedaan status gizi bayi usia 0-6 bulan yang diberi ASI Eksklusif dan tidak Eksklusif di BPS Suratni Bantul Yogyakarta.

Adapun penelitian sependapat dengan penelitian tersebut yang dilakukan oleh Karuniawati (2016), dengan judul penelitian perbedaan status gizi bayi berumur 4-6 bulan pada pemberian ASI Eksklusif dengan ASI Non Eksklusif menunjukkan bahwa terdapat nilai $\mathrm{p}$ 
$=0,000 \quad(\mathrm{p}<0,05)$ yang artinya terdapat perbedaan yang signifikan antara status gizi bayi berumur 4-6 bulan yang diberikan ASI Eksklusif dengan ASI Non Eksklusif. diperoleh dari 40 bayi yang diberikan ASI Eksklusif mempunyai status gizi lebih baik dibandingkan dengan tidak diberikan ASI secara Eksklusif. Status gizi buruk lebih banyak ditemukan pada kelompok bayi yang tidak diberikan ASI secara Eksklusif.

Menurut peneliti, perbedaan signifikan antara bayi yang diberi ASI Eksklusif dan tidak ASI Eksklusif dapat dikurangi dengan penyuluhan mengenai ASI Eksklusif, penggalakan program ASI Eksklusif, menerapkan Inisiasi Menyusu Dini (IMD) saat bayi baru lahir dan melakukan pendidikan kesehatan (penkes) kepada ibu-ibu tentang pengetahuan kebutuhan nutrisi pada bayi bahwa pada bayi yang diberi ASI Eksklusif pemenuhan nutrisinya akan terpenuhi karena kandungan didalam ASI yang ideal untuk kebutuhan nutrisi bayi serta pemberian ASI yang praktis dan prinsip on demand (bayi yang menentukan kapan ia mau menyusu dan seberapa lama dia menyusu). Adapun penkes kepada ibu-ibu tentang pengetahuan kebutuhan nutrisi pada bayi yang tidak diberikan ASI Eksklusif atau susu formula yakni cara penyajiannya yang harus tepat, jadwal pemberian susu formula sebaiknya diberikan 23 jam sekali dengan takaran air 185-200 ml dan takaran susu harus sesuai seperti yang tertera di kemasan susu, sehingga susu formula mampu mengganti ASI dan memenuhi kebutuhan nutrisi pada bayi.

\section{Kesimpulan}

Kesimpulan pada penelitian ini yaitu ada perbedaan status gizi antara bayi usia 6 bulan yang diberi ASI Eksklusif dan tidak diberikan ASI Eksklusif di Puskesmas Kampung Dalam Tahun 2018.Saran untuk Puskesmas Kampung Dalam agar dapat lebih mengoptimalkan pemberian konseling, penyuluhan dan pendidikan kesehatan kepada ibu yang memiliki bayi usia 0-6 bulan untuk memberikan ASI secara Eksklusif yang bertujuan untuk perbaikan status gizi bayi usia 0-6 bulan.

\section{Daftar Pustaka}

Dinas Kesehatan Provinsi Kalimantan Barat. 2017. Profil Kesehatan Kalimantan Barat. Pontianak: Dinas Kesehatan

Fikawati, Sandra, dkk. 2015. Gizi Ibu dan Bayi. Jakarta: PT Raja Grafindo Persada

Hapsari, Rani Ayu. 2012. Perbedaan Status Gizi Bayi Usia 0-6 Bulan yang di Beri ASI Eksklusif dan Tidak Eksklusif di BPS Suratni Bantul Yogyakarta. http://digilib.unisayoga.ac.id, diakses tanggal 19 Februari 2018 jam 17.49 WIB

Kemenkes RI. 2017. Pedoman Penyelenggaraan Pekan ASI. Jakarta: Kementrian Kesehatan Republik Indonesia

Khazanah, Nur. 2011. ASI atau Susu Formula ya ?. Yogyakarta: Flash Book

Kurnia, Widiastuti. 2013. Hubungan Pemberian ASI Eksklusif dengan Status Gizi Balita usia 6-24 bulan di Kampung Kajanan, Buleleng Tahun 2013. http://ejournal.undiksha.ac.id, diakses tanggal 12 Maret 2018 jam 17.26 WIB

Marimbi, Hanum. 2010. Tumbuh Kembang, Status Gizi dan Imunisasi Dasar Pada Balita. Yogyakarta: Nuha Medika

Simarmata. 2009. Gizi Dalam Daur Ulang Kehidupan. Jakarta: EGC 
Sularno, Agus. 2012. Hubungan Pemberian ASI Eksklusif dan Status Gizi dengan Frekuensi Diare pada bayi usia 0-4 bulan di Puskesmas Warungasem Kabupaten Batang. http://digilib.unimus.ac.id diakses tanggal 23 Maret 2018 jam 13.29 WIB
Sulistyoningsih, Hariyani. 2011. Gizi Untuk Kesehatan Ibu dan Anak. Yogyakarta: Graha Ilmu.

Susilowati. 2016. Gizi dalam Daur Kehidupan. Bandung: PT Refika Aditama 